\title{
Kábítószerügyi helyzetkép - Magyarország 2017 kiadványajánló
}

\author{
Drug Overview - Hungary 2017 Issue Proposal
}

\author{
Szerző: Cseh-Szatmári Dóra $\square$ \\ Nemzeti Drog Fókuszpont
}

Beküldve: 2018. 02. 20.

doi: 10.24365/ef.v59i1.241

Kulcsszavak: drog; kábítószer-helyzet; Magyarország; éves jelentés

Keywords: drug; drug-situation; Hungary; annual report

2017 decemberében jelent meg a Nemzeti Drog Fókuszpont kiadványa, a Kábítószerügyi helyzetkép - Magyarország 2017 címmel. ${ }^{1}$ A kábítószer-helyzet monitorozásáért felelős fókuszpont minden évben elkészíti Éves jelentését a Kábítószer és Kábítószerfüggőség Európai Megfigyelőközpontja (EMCDDA, European Monitoring Centre for Drugs and Drug Addiction) számára a magyarországi droghelyzet aktualitásairól, a kiadást megelőző év statisztikai adatai alapján. Az Éves jelentés rendkívül részletes, főleg szakemberek számára készül. A nemrég megjelent tájékoztató kiadvány közreadásának célja, ezen Éves jelentés rövidített és közérthetőbb bemutatása.

A kötet elején infografikák emelik ki az alapvető információkat a hazai statisztikákról és Magyarország Európai Unión belüli kábítószer-használati adatairól. A kiadvány végén részletesebb statisztikai táblák segítik a mélyebb tájékozódást.

Az 1. ábrából (Horváth et al., 2017) pillanatképet kapunk a magyarországi kábítószer-helyzetről, és a kiadványban bemutatott témákról, adatokról.

Az öt nagyobb tartalmi egységre osztott könyv a Nemzeti Drogellenes Stratégia és Szakpolitikai Program bemutatásával indul, melyben az aktuális nemzeti drogellenes stratégiát és szakpolitikai programot, az új pszichoaktív anyagokkal kapcsolatos jogi szabályozási kereteket, valamint a Korai Jelzőrendszer múködését és az elítéltek számát ismertetjük. A következő tartalmi egységben a hazai kábítószer-kínálatról és piacról összegyűjtött információkat tekintjük át. Összefoglaljuk a legfrissebb kábítószer-kereskedelmi adatokat a lefoglalástól a szállításon át, az utcai árakig, és a kábítószerrel kapcsolatos bűncselekmények számáig. A harmadik nagyobb egységben bemutatjuk a szerhasználati mintázatokat az általános népességben, ezen belül a felnőtt- és az iskoláskorúak körében, továbbá a problémás szerhasználat jellemzőin túl, a kezelési válaszlépéseket is. A kábítószer-fogyasztással összefüggő ártalmak ismertetésével zárjuk a fejezetet, úgy mint a fertőző betegségek, kockázati magatartások és halálesetek adatai. A negyedik részben összefoglaljuk a drogprevenciós és ártalomcsökkentő beavatkozások aktuális helyzetét, bemutatjuk a hazai kábítószer-használók járóbetegés fekvőbeteg ellátórendszerét. Az ötödik fejezet a börtön, mint speciális kábítószer-használati tér jellemzőit és szakmai válaszait tárja fel. A kiadvány a Nemzeti Drog Fókuszpont munkásságának bemutatásával zárul. Az olvasó megismerheti feladatainkat, honlapunkat, korábbi kiadványainkat és partnereinket. 


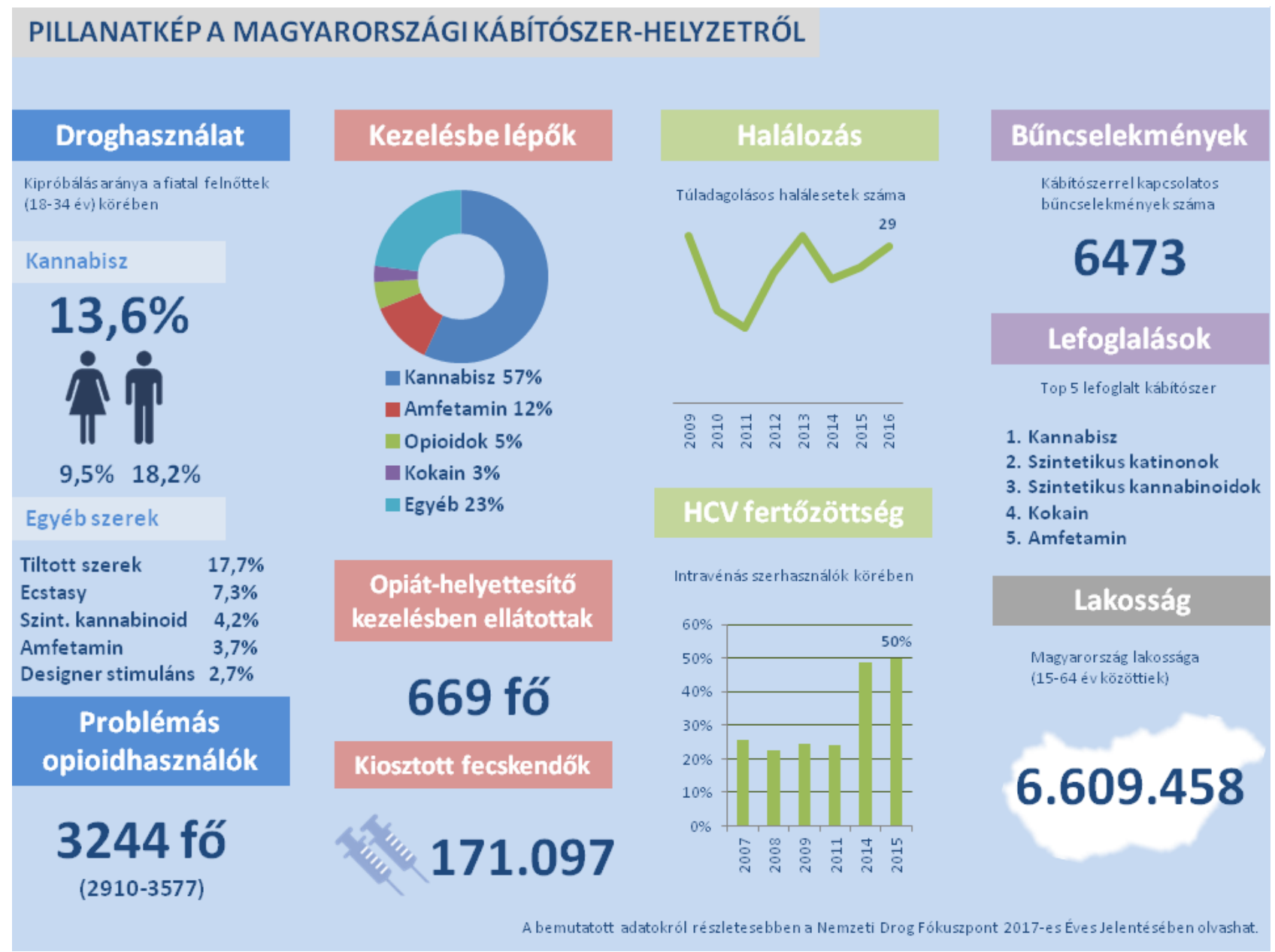

Forrás: Horváth et al., 2017

Az utóbbi években jelentősen átalakult a hazai és európai kábítószer-helyzet, ami az új pszichoaktív anyagok megjelenésének köszönhető. A változás nem csak a kábítószer-fogyasztás jellemzőiben, hanem a megjelenő ártalmakban is mérhető. Az újonnan felbukkanó anyagok kiemelt fontosságúvá tették a monitorozási, és a kockázatértékelési rendszert, továbbá az új jogi keretek bevezetését. Mindez hatással van a kábítószerpiacra és a bűnügyi adatokra is. A kiadvány bemutatja, hogyan alakultak ezen változások 2016-ban Magyarországon.

A kiadvány letölthető a Nemzeti Drog Fókuszpont honlapjáról: www.drogfokuszpont.hu

\section{HIVATKOZÁSOK}

\footnotetext{
${ }^{1}$ Horváth G. C., Zsuzsa K., Anna P., Ágnes P. (2017). Kábítószerügyi helyzetkép - Magyarország 2017. Budapest: Nemzeti Drog Fókuszpont.
} 